Prof. J. E. Smith, F.R.S.

The Council of the Marino Biological Association has appointed Prof. J. F. Smith to be director of the Marine Biological Laboratory at Plymouth in succession to Dr. F. S. Russell. Prof. Smith holds the chair of zoology at Quoen Mary Collego, London, and is vice-principal of the College. He is chairman of the National Committeo for Biology, chairman of the Grants Committeo (Biology) of the Department of Scientific and Industrial Research, and chairman of the Advisory Committee on the Dove Marine Laboratory to the Development Commission. Ho is a member of the British National Antaretic Survey Committee of the Royal Society, and the Biological Unit of this Committee is attached to his Department. $\mathrm{He}_{\Theta}$ is a Trusteo of the British Museum (Natural History). He has made outstanding contributions to our lnowledge of tho nervous system of echincdorms and other marine animals, and to the embryology of marine animals and the ecology of the marine fauna.

\section{Industrial Metallurgy at the College of Advanced Technology, Birmingham: Prof. J. C. Wright}

Dr. JoHn C. WRIGHT has been appointed professor of industrial metallurgy at tho College of Advanced Technology, Birmingham, as from October 19, 1964. Prof. Wright, who is 34 years of age, was educated at the Grammar School, Dudley. Joining tho Devolopment and Research Department of the Mond Nickel Co., Ltd., in Birmingham in 1948, he studied part-time at the College of Technology for the external B.Sc. degree of Loridon University, and was awarded this with first-class honours in 1954. After graduating he joined Imperial Chemical Industries Motals Division in Birmingham as a technical officer to assist in the devolopment of titanium-melting tochniques and, in 1956, he was awarded a senior research followship at Wolverhampton and Staffordshire Tochnical Collego to work on problems associated with pulverized fuel-fired gas turbines and was awarded tho Ph.D. degree of the University of London in 1958. In the same year he was appointed to the staff of the College of Advanced Technology, Birmingham, as a senior lecturer in metallurgy and, in 1959, ho took up his present position at the college as reader in industrial metallurgy. In 1961, Dr. Wright was elected a momber of the Council of the Institution of Metallurgists. His prosent research interests are associatod with the applied physical metallurgy of the doformation of metals-particularly of the newer metals.

\section{Enrico Fermi Professorship of Physics, Columbia Univer-} sity: $\quad$ Prof. Tsung-Dao Lee

DR. 'Tsung-DAo LeE, Nobol laureate and professor of physics in Columbia University, has boen appointed the first incumbent of the newly established post of Enrico Fermi profossor of physics in the University. Dr. Lee sharod the 1957 Nobol Prize in Physics with Dr. Chen Ning Yang, member of the Instituto for Advanced Study, Princeton University, for their research disproving the conservation of parity principle. At that time, Dr. Lee was thirty years old, the youngest full professor in modern times at Columbia. Born in Shanghai on November 25, 1926, Tsung-Dao Lee graduated in 1943 from the Kiangsi Middlo School in Kanchow. He then attended the National Chekiang Univorsity in Kweichow but, in 1945, fled from advancing Japanese invaders to Kunming, whoro ho attended the National Southwost Associated University. For his work in physies he was awarded a Chinese Government fellowship in 1946, which enabled him to study at the University of Chicago, where he recoived his Ph.D. in 1950. Dr. Le日 wont to Columbia as an assistant profossor from the Instituto for Advanced Study in 1953, and bocame a full professor in 1956. During 1960-62 he served as professor of physics in tho Institute for Advanced Study, and at the same time served as adjunct professor of physics at Columbia. He returned to Columbia as a full-timo member of the teaching staff in 1962. During the past summer Dr. Lee taught in Varenna, Italy, and spent two and a half months carrying out research in Geneva, Switzerland.

Enrico Fermi, in honour of whom tho now professorship was namod, was also a Nobel laureate in physics and served as professor of physics in Columbia during 1939-45. He helped to build the first atomic pilo at Columabia and wont to the University of Chicago on loavo from Columbia in 1942 whon the Manhattan P'roject, which døvoloped the atom bomb, was transforred to the Chicago institution. Dr. Fermi died in 1954.

\section{Gold Medal of the Royal Astronomical Society of \\ Great Britain: Dr. Maurice Ewing}

Dr. MaURICE Ewing, director of Lamont Geological Observatory, Columbia University, has been awarded the Gold Medal of the Royal Astronomical Society of Great Britain for his contributions to marine geophysics. It is the first Gold Medal the Royal Astronomical Society has given specifically for geophysical work. From now on the society will award two Gold Medals, one for astronomical and one for geophysical work. The citation recalls that, in 1949 Dr. Ewing was made director of the Lamont Geological Observatory, Palisades, N.Y., which is now "perhaps the most comprehensive geological and geophysical research unit in the world. Over the yoars the two aspects of Fwing's work, geophysical work at sea and the study of surface waves as a method of gaining more information concerning the crustal and maxitle rocks of the earth, have gone from strength to strength, with new metheds constantly boing developed. The work at sea now requires two deop-sea research vessels, and there are no oceans where Lamont scientists have not been working. In marine research, Ewing's name will always be coupled with turbidity currents, abyssal plains, mid-ocean ridges, and crustal thicknesses, and in seismology with tho dispersion of Love and Rayleigh waves and tho application of this study to the understanding of the Farth's deep structure".

\section{H. B. Bigelow Medal in Marine Science:}

\section{Dr. B. C. Heezen}

THe Bigelow Medal, established in 1960, is awarded by the Woods Hole Oceanographic Institution for "significant inquiries into the phenomena of the sea". Dr. Heezen, the third recipient, is assistant professor of geology at Columbia University, and his contribution to marine science lies in the field of marine geology, particularly the physiography of the Atlantic and Indian Oceans. His interpretation of the sedimentary and tectonic processes governing the physiography of the ocean floor has been developed in the light of energetic work both in the laboratory and in the field.

\section{Science in Parliament :}

National Parks

THE debate in the House of Lords on November 10 and 11 on the Address to the Throne ranged widely. Following Lord Mitchison's statement that National Parks would fall within tho responsibilities of the Minister of Land and Natural Resources, Lord Molson specifically urged the need for legislation to increase the powcrs of the National Parks Commission. The Standing Committen on National Parks of the Council for the Preservation of Rural England had written some months ago to the Prime Minister on the whole subject of the preservation of amenities, both within and without the National Parks. The Prime Minister had invited them to propare a full memorandum and had stated that this would be taken into account when the Government formulated its land policy. Lord Molson said that the memorandum had just reached its final form and would shortly be sent to the new Government, but in replying for the Government 